\title{
LEGAL POSSIBILITIES OF FEDERAL RAILROAD INCORPORATION
}

Eighty-four per cent of the railroads are knocking at the doors of Congress for federal charters. Chambers of Commerce, Boards of Trade, and other business organizations are steadily supporting the application. On the other hand th: State Commissions are vigorously opposing. One of the questions propounded by the Joint Committee of the Senate and House on the railroad problem is on this subject. ${ }^{1}$

The railroads seem to have the better of the argument. They submit that regulation by nearly forty conflicting, duplicating, and overlapping commissions is intolerable, and that there should be but one. ${ }^{2}$ They claim that the Union was formed largely to

1 Circular of Joint Committee of Senate and House (Nov. I916): ". . whether any national legislation is required as to the organization of carriers in interstate commerce in the nature of national incorporation, permissive or compulsory, or in the nature of national holding companies under which State corporations may be controlled and unified in their operations in the interest of interstate commerce, and what form of national legislation for the incorporation of carriers or for holding companies owning the stock of State companies, is desirable. How will national incorporation affect the police powers of the States over railroads operating within their boundaries? Will it be advisable, as in the case of the national banks, for the National Government to prescribe a uniform rule for the taxation by the States of railroad properties and securities?"

2 Senator Underwood, in an address delivered Feb. 4, 1916, said: "We must consider the wisdom of substituting one master for the forty-nine masters that regulate our commerce to-day."

Howard Elliott, in an address Feb. 8, 1916, said: "To-day the carriers of interstate commerce are the servants of forty-nine masters, of conflicting powers and desires, and if it be true that no man can successfully serve two masters, how confusing and inefficient must be the mental state of him who must serve the United States and a number of sovereign States."

The Republican national platform in the presidential campaign of 1916 contained the following plank: "Interstate and intrastate transportation have become so interwoven that the attempt to apply the two, and often several, sets of laws to its regulation has produced conflicts of authority, embarrassment in operation and inconvenience and expense to the public. The entire transportation system of the country has become essentially national. We, therefore, favor such action by legislation, or, if necessary, through an amendment to the Constitution of the United States, as will result in placing it under exclusive Federal control."

[207] 
protect interstate commerce; that it is the duty of Congress to provide the protection; and that the only way to give it is by federal charters. ${ }^{3}$ They say that they cannot furnish proper

${ }^{3}$ On this subject Mr. Thom, the General Counsel of the Southern Railway, at a hearing before the House Interstate Commerce Committee in Washington on Feb. 29, I916, quoted John Fiske, The Critical Period of American History, pp. I7I-75, as follows:

"Meanwhile the different States, with their different tariff and tonnage acts, began to make commercial war upon one another. No sooner had the other three New England States virtually closed their ports to British shipping than Connecticut threw hers wide open, an act which she followed up by laying duties upon imports from Massachusetts.

"Pennsylvania discriminated against Delaware, and New Jersey, pillaged at once by both her great neighbors, was compared to a cask tapped at both ends. The conduct of New York became especially selfish and blameworthy. That rapid growth which was so soon to carry the city and state to the position of primacy in the Union had already begun. After the departure of the British the revival of business went on with leaps and bounds. The feeling of local patriotism waxed strong, and in no one was it more completely manifested than in George Clinton, the Revolutionary general, whom the people elected governor for six successive terms. . . . It was his first article of faith that $N^{\top}$ ew York must be the greatest State in the Union. But his conceptions of statesmanship were extremely narrow. In his mind the welfare of New York meant the pulling down and thrusting aside of all her neighbors and rivals. . . . Under his guidance, the history of New York, during the five years following the peace of 1783 , was a shameful story of greedy monopoly and sectional hate. . . .

"A single instance which occurred early in 1787 , may serve as an illustration. The city of New York, with its population of 30,000 souls, had long been supplied with firewood from Connecticut and with its butter and cheese, chickens and garden vegetables from the thrifty farms of New Jersey. This trade, it was observed, carried thousands of dollars out of the city and into the pockets of detested Yankees and despised Jerseymen. It was ruinous to domestic industry said the men of New York. It must be stopped by those effective remedies of the Sangrado school of economic doctors, a navigation act and a protective tariff. Acts were accordingly passed, obliging every Yankee sloop which came down through Hell Gate, and every Jersey market boat which was rowed across from Paulus Hook to Cortlandt Street, to pay entrance fees and obtain clearances at the custom house, just as was done by ships from London or Hamburg; and not a cartload of Connecticut firewood could be delivered at the back door of a country house in Beekman Street until it should have paid a heavy duty. Great and just was the wrath of the farmers and lumbermen. The New Jersey Legislature made up its mind to retaliate. . . . Connecticut was equally prompt. At a great meeting of business men, held at New London, it was unanimously agreed to suspend all commercial intercourse with New York. Every merchant signed 
transportation without strong financial support, which is practically impossible under present commission rule.

Ever since the formation of our government the tendency has been towards centralization of power at Washington. Assuming then that federal charters will be granted the question arises: What will be their legal status? And more important still, How can those charters be framed to carry out the public will?

It is no longer doubted that Congress has the power to grant federal charters to railroads engaged in interstate commerce. Several such charters were granted in the sixties to encourage railroad building to the Pacific coast. ${ }^{4}$ The Supreme Court holds that a federal railroad charter is legal as a means of regulating interstate commerce and establishing post roads. ${ }^{5}$

an agreement, under penalty of $\$ 250$. for the first offense, not to send any goods whatever into the hated State for a period of twelve months. By such retaliatory measures, it was hoped that New York might be compelled to rescind her odious enactment. But such meetings and such resolves bore an ominous likeness to the meetings and resolves which in the years before 1775 had herald a state of war; and but for the good work done by the federal convention another five years would scarcely have elapsed before shots would have been fired and seeds of perennial hatred sown on the shores that look toward Manhattan Island."

The Supreme Court of the United States in the Shreveport case (1914) 234 U. S. 342,360 , a few months ago said: "It was recognized at the beginning that the nation could not prosper if interstate and foreign trade were governed by many masters."

4 The first one was that of the Union Pacific granted July 1,1862 , I2 U. S. St. 489 . In 1864 Congress chartered the Northern Pacific R. R. Co. and authorized to build a railway line from a point in Minnesota or Wisconsin to Puget Sound. I3 U. S. St. 365. In 1866 Congress chartered the Atlantic \& Pacific R. R. Co. to construct a railroad from a point in Missouri to the Pacific Ocean. I4 U. S. St. 292. In I871 Congress chartered the Texas Pacific Railroad to construct a railroad in California and Texas. 16 U. S. St. 573.

${ }^{5}$ Califormia v. Pacific R. R. (1888) I27 U. S. I, 39. The court in referring to the above Acts of Congress said: "It cannot at the present day be doubted that congress, under the power to régulate commerce among the several states as well as to provide for postal accommodations and military exigencies, had authority to pass these laws. The power to construct or to authorize individuals or corporations to construct national highways and bridges from state to state is essential to the complete control and regulation of interstate commerce." See also Mercantile $T$. Co. v. Texas, etc. Ry. (1914) 216 Fed. 225 Congress may create a corporation to build a bridge across navigable waters between two states. Luxton, etc. v. North River Bridge Co. (1894) I53 U. S. 525. 
Congress at various times has granted various kinds of federal charters and its power in that respect is no longer doubted. ${ }^{B}$

This brings us to a more difficult question. May not Congress curb state interference with railroads by greater congressional regulation, without federal incorporation? Will not the decisions of the Supreme Court and the rulings of the Interstate Commerce Commission suffice? The Shreveport decision, holding that a state cannot unreasonably reduce intrastate railroad rates to eliminate interstate competition, $i$. e., interstate commerce, is pointed to as proof that the courts can work out the problem. ${ }^{7}$

The objection is that judicial control inevitably entails interminable delay and inextricable confusion. Most astonishing decisions, defining what is intrastate commerce as distinguished from interstate commerce, are being handed down in state and federal courts. One of the very latest is by the Supreme Court of Missouri, adopting the reasoning of an article published in $1914 ;^{8}$ namely, that interstate commerce, requiring a general system or uniformity of regulation, is exclusively within the jurisdiction of Congress, whether exercised or not; but as to subjects which, owing to local conditions, may also be regulated by state regulation, the jurisdiction of Congress is exclusive only

The power of Congress to incorporate a bank was contested but the Supreme Court sustained it. McCulloch v. Maryland (18rg) 4 Wheat. (U. S.) 316. In I79r the first Congress incorporated the first Bank of the United States. I U. S. St. IgI. The charter expired and in 1815 Congress passed a new charter, but the President vetoed it. Annals of Congress, 13th Congress, Vol. 3, p. 208. In 1816 Congress incorporated the second Bank of the United States. 3 U. S. St. 266 . In $186_{3}$ Congress passed a general statute for the incorporation of national banks. I2 U. S. St. 665. The present Federal Reserve Act was enacted in r913. $38 \mathrm{U}$. S. St. 25I. In 1865 Congress incorporated the Freedmans Savings \& Trust Co. I3 U. S. St. 510; in 1865 the National Asylum for Disabled Soldiers, I3 U. S. St. 509; in I872 the Centennial Board of Finance, 17 U. S. St. 203; in 1889 the Maritime Canal Company of Nicaragua, 25 U. S. St. 673. Congress has created corporations within the District of Columbia; for instance, in 1876 a corporation to do an insurance business in that District. I9 U. S. St. 380 . Congress in the case of the Cumberland or National Road, from the Potomac across the Alleghenies to the Ohio, authorized the construction of a public highway connecting several states. See Indiana v. United States (1893) I48 U. S. 148.

${ }^{7}$ Houston, etc. Ry. v. United States (I914) 234 U. S. 342.

828 HARv. L. REv. 34. 
when exercised. ${ }^{9}$ But how many years would it take to work out the application of that rule to thousands of diversified situations, to which it would apply throughout this vast country. Then, there is the rule that a railroad shipment from one point in a state to a point in the same state, but passing in transit through another state, is not interstate commerce in tax matters, ${ }^{10}$ but is interstate commerce as to the Interstate Commerce Act. ${ }^{11}$ A shipper's claim to be reimbursed for expense for placing inside doors on cars on an interstate shipment may be sustained as to intrastate shipments under the New York statute, ${ }^{12}$ but not in the federal courts as to interstate shipments until after the Interstate Commerce Commission has passed upon the matter. ${ }^{13}$ Another decision of the Supreme Court is that a shipment over an intrastate railroad may be interstate commerce and subject to the Interstate Commerce Act where there is a connecting line agreement for through carriage, ${ }^{14}$ and the later Galveston Terminal decision is that the Terminal Company was in fact and in law a part of the railroad system of the Southern Pacific Company, and, hence, subject to the Interstate Commerce Act. ${ }^{15}$ Still another decision declares that corn shipped from South Dakota to Texarkana, Texas, is intrastate traffic as to Texas, it appearing that the corn on arriving at Texarkana was transferred to the connecting railroad for further transportation to another Texas point on a separate bill of lading. ${ }^{18}$ On the other hand, where coal is shipped from a mine in Ohio to an Ohio lake port and there loaded upon a boat to be sent to other states; the Ohio State Commission has no jurisdiction over such shipment. ${ }^{17}$

\footnotetext{
- Lusk v. Atkinson (1916) $186 \mathrm{~S} . \mathrm{W}$. (Mo.) 703.

${ }^{10}$ Lehigh Valley R. R. v. Pennsylvania (1892) I45 U. S. 192

11 United States v. D. L. \& W. R. Co. (I907) I52 Fed. 269; Milk Producers Co. v. D. L. \& W. R. Co. (1897) 7 I. C. C. Rep. 92; New Orleans Cotton Exchange v. Cincinnati, etc. $R y$. (1888) 2 I. C. C. Rep. 375 ; Hanley v. Kansas City Southern Ry. (1903) 187 U. S. 617.

12 Loomis v. Lehigh Valley R. R. (1913) 208 N. Y. 312.

${ }^{13}$ Loomis v. Lehigh Valley R. R. (1916) 240 U. S. 43.

14 Cincinnati, etc. Ry. v. Interstate C. C. (I896) I62 U. S. I84. A similar decision is that of Buer, etc. Co. v. Denver \& R. G. R. R. (I914) 233 U. S. 479.

${ }_{15}$ Southern Pacific, etc. Co. v. Interstate C. C. (I9II) 219 U. S. 498.

${ }^{18}$ Gulf, Col. \& Santa Fe, etc. v. Texas (1907) 204 U. S. 403.

17 Railroad Commission of Ohio v. Worthington Receivers (I912) 225 U. S. ror.
} 
The courts have travelled far along the lines which were avoided by the Supreme 'Court of the United States over sixty years ago, when it was argued that a purely intrastate act of transportation might become interstate if it was one of a series of acts and transactions which were interstate. The court held that this was not the law. ${ }^{18}$

Judge Cooley in his work on Constitutional Limitations says $:^{18}$

"The line of distinction between that which constitutes an interference with commerce, and that which is a mere police regulation, is sometimes exceedingly dim and shadowy, and it is not to be wondered at that learned jurists differ when endeavoring to classify the cases which arise."

The boundary line between intrastate commerce and interstate commerce is shadowy and wavering, fluctuating from time to time in response to politics and trade necessities. It has been a legal and political issue for two generations. It would be hazardous for anyone to assert that Congress may eliminate it altogether merely by Act of 'Congress, or that courts will eliminate it by decisions. Even if they should attempt it, there would be doubt, confusion, delay, and interminable litigation.

Fifty years have not sufficed to work out a remedy for transportation ailments. Meantime the patient is dying. The railroads have got to have money to keep up with the growth of the nation in population and commerce, but money they cannot get.

18 Veazie v. Moor (1852) I4 How. (U. S.) 568, 574. The court said : "A pretension as far reaching as this would extend to contracts between citizen and citizen of the same state, would control the pursuits of the planter, the grazier, the manufacturer, the mechanic, the immense operations of the collieries, and mines and furnaces of the country; for there is not one of these avocations the results of which may not become the subjects of foreign commerce,-and be borne, either by turnpikes, canals, or railroads from point to point within the several states, towards an ultimate destination like the one above mentioned. Such a pretension would effectually prevent or paralyze every effort at internal improvement by the several states; for it cannot be supposed that the states would exhaust their capital and their credit in the construction of turnpikes, canals and railroads, the remuneration derivable from which, and all control over which, might be immediately wrested from them, because such public works would be facilities for commerce which, whilst availing itself of those facilities, was unquestionably internal, although intermediately or ultimately it might become foreign."

19 P. 586. 
The investor is afraid of regulation. This is the crux of the trouble. MIr. Prouty, the veteran Interstate Commerce Commissioner, says :

"This is the point at which regulation will break down if at all. Can private capital be induced, under the treatment which is accorded that capital by the regulating body, to invest? If Government ownership ever comes in the United States it will probably be because private capital cannot be obtained in sufficient amounts to afford an adequate service."

Like the government, the railroads are always passing the hat. If they cannot get the money the public will suffer and then will come government ownership as a dernier resort. In other words, state interference with the railroads must be stopped by some more summary remedy than courts and commissions. The decisions are a bewildering mass of fine distinctions, a labyrinth of inconsistent and contradictory rulings, and no one knows what will come next. It is a Gordian knot. Is there no way of cutting it?

There certainly is. Federal incorporation. A federal railroad charter could expressly forbid state regulation of intrastate rates and in fact forbid any state regulation of the railroads owned by such federal railroad corporations. This would be constitutional. The underlying reason of the complete power of Congress over railroads owned by federal railroad corporations is plain. Congress in creating a corporation has, and may retain, full power over its own creation as to its property, rates, elections and practices, its bond issues and its stock issues. Congress could exercise that power as it pleased from time to time. Only a few months aga the Supreme Court, in describing a federal railroad charter, ${ }^{20}$ quoted from one of its earlier decisions as follows:

"The charter of incorporation not only creates it [the corporation] but gives it every faculty which it possesses. The power to acquire rights of any description, to transact business of any description, to make contracts of any description, to sue on those contracts, is given and measured by its charter, and that charter is $a$ law of the United States. This being can acquire no right, make no contract, bring no suit, which is not author-

${ }^{20}$ Bankers Trust Co. v. Texas \& Pac. Ry. (19I6) 24I U. S. 295, 305. 
ized by a law of the United States. It is not only itself the mere creature of a law, but all its actions and all its rights are dependent on the same law. Can a being, thus constituted, have a case which does not arise literally, as well as substantially, under the law? Take the case of a contract, which is put as the strongest against the bank .. . The act of Congress is its foundation. The contract could never have been made but under the authority of that act. The act itself is the first ingredient in the case, is its origin, is that from which every other part arises. The other questions may also arise, as the execution of the contract, or its performance, cannot change the case, or give it any other origin than the charter of incorporation. The action still originates in, and is sustained by, that charter."

There are only a few decisions on the power of Congress to forbid a state regulating the intrastate rates of a federal railroad company but they point the way very clearly. In I894 the Supreme Court held that Texas might regulate the intrastate rates of the Texas and Pacific Railway Company, a federal railroad corporation, but this was because Congress had not prohbited it. $^{21}$

\footnotetext{
${ }^{21}$ Reagan v. Mercantile Trust Co. (1894) I54 U. S. 4I3, 4I6. The court said: "Similarly we think it may be said that, conceding to Congress the power to remove the corporation in all its operations from the control of the State, there is in the act creating this company nothing which indicates an intent on the part of Congress to so remove it, and there is nothing in the enforcement by the State of reasonable rates for transportation wholly within the State which will disable the corporation from discharging all the duties and exercising all the powers conferred by Congress. By the act of incorporation Congress authorized the company to build its road through the State of Texas. It knew that, when constructed, a part of its business would be the carrying of persons and property from points within the State to other points also within the State, and that in so doing it would be engaged in a business, control of which is nowhere by the Federal Constitution given to Congress. It must have been known that, in the nature of things, the control of that business would be exercised by the State, and if it deemed that the interests of the nation and the discharge of the duties required on behalf of the nation from this corporation demanded exemption in all things from state control, it would unquestionably have expressed such intention in language whose meaning would be clear. Its silence in this respect is satisfactory assurance that, in so far as this corporation should engage in business wholly within the State, it intended that it should be subjected to the ordinary control exercised by the State over such business. Without, therefore, relying at all upon any acceptance by the railroad corporation of the act of the
} 
About six months later in that same year, Mr. Justice Brewer, sitting at circuit, passed upon the federal charter of the Union Pacific Railroad Company and held that Nebraska might regulate the intrastate rates because Congress had not reserved to itself the sole and absolute control of all rates in granting the federal charter. ${ }^{22}$

On appeal, the Supreme Court affirmed this view and assumed that Congress had the power to exercise exclusive control over intrastate rates of a federal railroad company. ${ }^{23}$

legislature of the State, passed in 1873 in respect to it, we are of opinion that the Texas and Pacific Railway Company is, as to business done wholly within the State, subject to the control of the State in all matters of taxation, rates, and other police regulations."

22 Ames v. Union Pacific Railway Co. (1895) 64 Fed. 165. The court said at p. I70: "It is insisted that the Union Pacific Railway Company cannot be subjected to the provisions of this statute, because it is a corporation created by congress, and as such, in the discharge of any of its functions, is subject only to the control of that body. The general question of the power of a state in respect to rates for local freight over a corporation organized under the laws of congress was considered in Reagan v. Trust Co. (1894) I54 U. S. 4I3, and it was there held that the mere fact that the corporation was so organized did not exempt it from state control in that respect. It was conceded in the opinion in that case that congress could wholly remove such a corporation from state control; but it was held that, in the absence of something in the statutes indicating an intention on the part of congress to so remove it, the state had the power to prescribe the rates for all local business carried by it. Of course, that decision is controlling."

${ }^{23}$ Sinythe v. Ames (I898) I69 U. S. 466, 521, 522. The court said: "It cannot be doubted that the making of rates for transportation by railroad corporations along public highways, between points wholly within the limits of a State, is a subject primarily within the control of that State. And it ought not to be supposed that Congress intended that, so long as it forbore to establish rates on the Union Pacific Railroad, the corporation itself could fix such rates for transportation as it saw proper independently of the right of the States through which the road was constructed to prescribe regulations for transportation beginning and ending within their respective limits. On the contrary, the better interpretation of the act of July I, I862, is that the question of rates for wholly local business was left under the control of the respective States through which the Union Pacific Railroad might pass, with power reserved to Congress to intervene under certain circumstances and fix the rates that the corporation could reasonably charge and collect. Congress not having exerted this power, we do not think that the national character of the corporation constructing the Union Pacific Railroad stands in the way of a State prescribing rates for transporting property on that road 
That was in 1898 . Three years previously the Supreme Court touched upon the same question incidentally. ${ }^{24}$ In 1873 the Supreme Court held that the railroad property of a federal railroad corporation might be taxed by a state, there being nothing in the charter prohibiting such taxation. ${ }^{25}$

Chief Justice Marshall in the McCulloch case in I819 laid down the broad principle governing this subject when he said:

"The sovereignty of a state extends to every thing which exists by its own authority, or is introduced by its permission; but does it extend to those means which are employed by congress to carry into execution powers conferred on that body by the people of the United States? We think it demonstrable that it does not. Those powers are not given by the people of a single State. They are given by the people of the United States to a government

wholly between points within its territory. Until Congress, in the exercise either of the power specifically reserved by the eighteenth section of the act of 1862 or its power under the general reservation made of authority to add to, alter, amend or repeal that act, prescribes rates to be charged by the railroad company, it remains with the States through which the road passes to fix rates for transportation beginning and ending within their respective limits."

24 Southern Pacific R. R. v. California (1895) I62 U. S. 9I, 125. The court said: "Of course, if Congress should think it necessary for the protection of the United States to declare such property exempted, that would present a different question."

${ }^{25}$ In Railroad Company v. Peniston (1873) 18 Wall. (U. S.) 5, 36, the court said: "It is therefore, manifest that exemption of Federal agencies from State taxation is dependent, not upon the nature of the agents, or upon the mode of their constitution, or upon the fact that they are agents, but upon the effect of the tax; that is, upon the question whether the tax does in truth deprive them of power to serve the government as they were intended to serve it, or does hinder the efficient exercise of their power." Mr. Justice Swayne concurring therein stated that Congress had power to prohibit such taxation if Congress saw fit. See also Van Brocklin v. State of Tennessee (1886) II7 U. S. 151, I77; Central Pacific R. $R$. v. California (1896) 162 U. S. 91, 125. The National Bank Act expressly authorized the states to tax the land and shares of stock of national banks. Act of Congress of June 3, I864, amended Feb. 10, 1868. Cf. McCulloch v. Maryland (18x9) 4 Wheat. (U. S.) 316; National Bank v. Commonwealth (1869) 9 Wall. (U. S.) 353; Owensboro Nat. Bank v. Owensboro (I899) I73 U. S. 664. This question will be very important if federal charters are granted to railroad companies, inasmuch as the states at present derive over $\$ 100,000,000$ annual revenue from the taxation of railroad property. It is extremely probable, however, that Congress would never prohibit such taxation. 
whose laws, made in pursuance of the constitution, are declared to be supreme. Consequently, the people of a single State cannot confer a sovereignty which will extend over them." 26

A federal railroad charter forbidding any state regulation of rates, or otherwise, would stop such regulation instantly. One act of prohibition is worth twenty years of litigation. Moreover, Congress may be induced to grant such federal railroad charters; but probably never could be induced to prohibit the states from regulating intrastate railroad rates on the theory that such regulation interfered with interstate commerce.

Assuming, then, that federal charters will be granted to unify regulations and to control issues of stock and bonds, will the railroad problem be solved thereby? Will that produce the necessary funds for railroad extensions and improvements? Decidedly not. Witness the old federal charters. They are nearly all extinct. Even the Union Pacific was foreclosed in I897 and only a few weeks ago the Texas Pacific, incorporated by Congress in 1871 , passed into the hands of a receiver. Its federal charter did not save it.

Here again the law points the way. The old Union Pacific charter from 'Congress allowed the government to name five directors. $^{2 \pi}$ A new federal charter might legally provide that the government name all of the directors. ${ }^{28}$ At present the

${ }^{26}$ McCulloch v. Maryland (1819) 4 Wheat. (U. S.) $316,429$.

27 (1862) 12 U. S. St. 49I ; (I864) I3 U. S. St. 36I.

28 Unless the original federal charters contain such a provision it is doubtful whether such a provision could be inserted later, even under the usual reserved right to amend charters. This reserved right to amend has decided limitations. It does not legalize a fundamental change in a charter. Cooley, Const. Lim. (5th ed.) p. 454; Close v. Glenwood Cemetery (1882) 107 U. S. 466 . It has been held particularly that changing the voting power of stockholders, after the charter has been granted, is a fundamental change, even under the reserved power to amend. Lord $v$. Equitable etc. Soc. (1909) I94 N. Y. 212. It is true that the constitutional prohibition against violation of a contract applies only to the states, but the constitutional provision as to "due process of law" accomplishes the same thing as to an Act of Congress. Sinking-Fund Cases (1878) 99 U. S. 700. Hence if the public is to name any of the directors under the proposed federal railroad charters, that provision should be put into the original charters themselves, or at least the original charter in reserving power to amend should expressly reserve the power to authorize the government to name the directors of the federal corporations. 
directors represent nobody except themselves. They do not represent the public, nor the government, nor the agricultural interests, nor the manufacturing, nor shipping interests. Strange to say they do not even represent the stockholders. The stockholders no longer attend the meetings and thousands do not even send in their proxies. They merely take their dividends and hope for more. They are a negligible quantity. But their money is not. Sixty years ago the railroads were local and the stockholders attended meetings. In New England a free pass was given for the day of the annual meeting. Now, however, gigantic corporations with hundreds of millions of capitalization and tens of thousands of stockholders, scattered far and wide, hold their annual elections hundreds of miles away from the stockholders. Personal attendance has become impossible and so the proxy system has grown up. The Union Pacific with its $\$ 321,835$, I IO of capital stock holds its annual meeting in Utah; the Southern Pacific with its $\$ 272,677,405$, in Kentucky. Stockholders' meetings have become a legal fiction. The directors have inherited their positions or have come in by a selfperpetuating process, or have taken office by default (the company being in trouble), or have broken in by a coup. If federal incorporation means a perpetuation of this system, it means a continuation of the present conflcit. The investor will still refuse to invest. Railroad facilities will fail and the whole plan of federal charters will break down.

There is another significant phase of the present system of control. It may be sectionalism but it is also fact. A year ago, of the II7 directors of the eight great railroad systems in the Mississippi Valley, only 23 were identified with that Valley. Ninety-two were in the east; 2 in California. New York had 58; Pennsylvania 20; Massachusetts 6 . And yet these eight great railroad systems are the warp and woof of the west. Without them the west would collapse. When it is remembered that the west has a majority of Congress and of the voters of the country, who can wonder, with such directors, that the west demanded the Interstate Commerce Commission and will soon demand public control of the railroads? Regulation has failed, and public control, the American people are determined to have In fact, the American people have already taken practical control through commissions and should now take complete control. This would abolish all commissions, so far as railroads are concerned, because if the directors were named by the government, 
regulation by commissions would be necessary. The directors would order done that which should be done, after the same investigation as prevails now. Prompt inquiry and quick decisive action would take the place of semi-judicial, semi-executive, semi-legislative commissions. Would not that be better than multiplication of subcommissions of the Interstate Commerce Commission as now proposed by the railroads?

But is not this the same as government ownership? And is it any improvement on the present way of selecting directors? The best way to answer these questions is to examine the ills to which we are now subject, apply the remedies, and watch the result.

For instance, assuming that we will have either federal railroad charters or government ownership, will the following troubles be solved best by (I) government ownership; (2) a federal railroad board naming the directors of the federal railroad corporations, hereinafter called the "Federal Railroad Board"; or (3) the federal railroad directors elected as they are now, under the state charters, this system being hereinafter referred to as the "Autocracy."

Excessive regulation. Some forty-five state commissions would be put out of business, so far as the railroads are concerned, by any one of the three plans mentioned above. The Interstate Commerce Commission on the other hand would be practically displaced only by government ownership or a Federal Railroad Board. The Autocracy could not do this.

Discriminations and Rebates. These also would cease under government ownership or a Federal Railroad Board. They will not cease under a continuation of the Autocracy.

Wasteful competition. Duplicate passenger trains and freight trains would be controlled and the wasteful competition would cease under government ownership or a Federal Railroad Board. It will not cease under a continuation of the Autocracy. The saving that could be made in this way is far beyond anything that the public now realizes, and particularly as to through passenger service between the Atlantic and the Pacific.

Wasteful regulation and litigation. Here, too, government ownership or a Federal Railroad Board would put an end to this waste. The saving in expense of commissions alone would be enormous, to say nothing of the expense of railroad officers, clerks, employees, etc. A continuation of the Autocracy will accomplish nothing in this respect. 
The above four elements of the railroad problem would be equally well taken care of by government ownership and by a Federal Railroad Board. They will not be cured by a continuation of the present system of electing directors. As to the remaining elements mentioned below, the result is still more striking.

Taxes. At present the states derive over $\$ 100,000,000$ annually from taxation of railroads. Under government ownership this would cease. Under a Federal Railroad Board or the Autocracy it would not cease, unless Congress expressly prohibited such state taxation, and that need not happen.

Money. Government ownership would start with a debt of from $\$ 15,000,000,000$ to $\$ 20,000,000,000$. The amount is staggering. In addition the government would have to furnish $\$ 1,000,000,000$ a year for several years for present railroad needs. A Federal Railroad Board would not in itself enable the railroads to sell enough stock and bonds to raise this $\$ 1,000$,$\infty, 000$ a year, but with complete public control thus taken by the government, the government would have to take the responsibility of guaranteeing a small dividend on the stocks issued by the new federal railroad corporations. ${ }^{2 \theta}$ On the other hand, federal railroad charters with a mere continuation of the present system of electing directors will not produce the money.

Railroad men point out that no double track railroad is found west of the Mississippi excepting one; that since January I, I9I5, only $\$ 12,910,520$ has been raised by the railroads by the issue of stock; that last year saw less new railroad construction than any year since the 'Civil War; that while the industrial development of the country is phenomenal the railroads are standing still, and that the American people will insist on new railroad facilities even if government ownership is necessary to obtain them. Meantime the waters are stirring and public discussion is boiling because trade is blocked for lack of cars, locomotives, and tracks. Coal lies at the mouth of the mines and grain at

\footnotetext{
${ }^{29}$ A proposed Act of Congress for incorporating federal railroad companies with directors to be named by a Federal Railroad Board; prohibition of State regulation; 3 per cent on the capital stock to be guaranteed by the government, with a possible extra 3 per cent to the stockholders if earned; all over 6 per cent to go to the government, was-drawn and published by the writer in a series of letters written to The Sun (New York, April, I916).
} 
way stations, while prices soar. The railroads have not the money and cannot get it.

Deficit in operation. There certainly would be a deficit in operation if we adopted government ownership. A Federal Railroad Board would be safer, because, as shown below, the mob of office seekers could be more easily kept out. It must be admitted that a continuation of the Autocracy will be safer still because the present railroad directors do not allow politicians to run the railroads.

Poor service; unnecessary service; undesirable extensions; waste; stagnation. Here too great abuses would arise under government ownership. They have arisen wherever governments have owned and operated the railroads except in Germany. A Federal Railroad Board would be better, and certainly could not be worse. A continuation of the present autocratic mode of electing directors will continue the present efficiency, but will also continue the present unnecessary competitive service and unnecessary competitive extensions.

Lower rates. Government ownership would give these on account of political pressure, but it would be at the expense of a great deficit, which would have to be made up by taxes, and hence lower rates produced in that way would be merely transferring money from tax payers to other pockets. A Federal Railroad Board could and would eliminate duplicate service and the saving would render possible lower rates. A continuation of present directors will accomplish nothing in this respect. On the contrary, present directors are continually clamoring for higher rates.

Politics. This is the most difficult and dangerous element of all. The country instinctively feels that government ownership is incompatible with our republican institutions. It would mean an office-holding oligarchy, which would dominate the government itself, in politics, finance, and policy. The history of government-owned railroads in other countries is well known. Their failures are disastrous enough to make our country pause, and no one as yet seriously advocates this ruinous experiment. If the government owned and operated the railroads they would be the happy hunting ground of ignorant voters and crooked politicians. It cannot be claimed, however, that politics necessarily would creep into a Federal Railroad Board. There is no government ownership of railroads in Great Britain, yet at the outbreak of the war the British government took over the rail- 
roads in the United Kingdom and has been operating them ever since by means of an executive committee composed of the general managers of the railroads themselves. In return the government practically guaranteed dividends to the railroad stockholders at the same-rate as before the war. The government takes all the receipts and pays all the expenses. It is government control without government ownership. Of course all this has been in time of war, but there is no reason why it is not equally possible in time of peace. It is a feasible plan to meet all railroad problems and has the additional advantage that it prepares in time of peace for national defense in time of war. It preserves the identity and separate existence of railroad corporations, and thus enables the government to keep politics out of their management. New York City has aided the railroad corporations to build its subway system at a cost of hundreds of millions of dollars. There has been no waste; neither has the city yielded to the clamorous demands of the suburbanites for unnecessary extensions. And there is no reason why a Federal Railroad Board is not as feasible for controlling the railroads as a Federal Reserve Board has proved to be for controlling the banks. Such a Federal Railroad Board would aid in keeping the railroads out of politics. It could be named by the President and confirmed by the Senate and could be given power to name the directors of the different federal railroad corporations. A plan of that sort would separate the railroads from the office hunters by five distinct and formidable lines of intrenchments.

(I) The President and Senate selecting the Federal Railroad Board would endeavor to get good men, free from politics, as has been done in the case of the Federal Reserve Board.

(2) The Federal Railroad Board itself would naturally seek for the best men to serve as directors of the federal railroad corporations. It would have no motive for doing otherwise..

(3) The railroad directors so named would feel the responsibility of selecting proper general managers. They would in a way be government officials.

(4) The general managers so selected would be interested most of all in having an efficient and non-political staff to operate their railroads.

(5) The hundreds of thousands of stockholders scattered throughout the country, desirous of larger dividends than a guaranteed 3 per cent, or thereabouts, would exert a most wholesome influence in keeping the railroads out of politics. They 
could even be given a voice by proxy in the selection of the Federal Railroad Board, and would make their influence felt as conservative investors. A million stockholders in one unified railroad system of control would be better than a half million stockholders in dozens of railroad corporations, as at present. As a final safeguard against political control, these million stockholders might well be given a limited veto power over the management.

It is true that a continuation of the present mode of selecting railroad directors will not put the railroads under the control of politicians, but on the other hand it will continue to subject the railroads to the attacks of politicians, with the result that federal railroad corporations cannot be financed and the money for necessary extensions and improvements cannot be obtained. Then the whole fabric will collapse and we will move swiftly to government ownership.

William W. Cook.

NEW YoRK BAR. 